\title{
IV. Agenda, or a collection of observations and researches, the results of which may serve as the foundation for a theory of the earth
}

\section{De Saussure}

To cite this article: M. De Saussure (1799) IV. Agenda, or a collection of observations and researches, the results of which may serve as the foundation for a theory of the earth , Philosophical Magazine Series 1, 5:18, 135-140, DOI: 10.1080/14786449908677129

To link to this article: http://dx.doi.org/10.1080/14786449908677129

曲 Published online: 18 May 2009.

Submit your article to this journal $\pi$

Џll Article views: 3

Q View related articles 5 
Ilints for the Formation of a Theory of 230 Eartb. $\quad \mathrm{I}_{35}$ loured fcoria than when the former varieties exift; a fpeck of plumbago is now only found here and there, and that of the fmalleft fize. When the quality of the metal is oxygenated (No. 4.), not only have the plates of carburet ditappeared, but alfo the coally colour on the external furface of the fcoria ; what now attaches to the bars, is nearly of the fame nature and colour as the lava emitted at the notch of the dam.

Thefe criterions are infallible; for, as the fufibility or carbonation of the metal is promoted in a direet ratio to the comparative quantity of the coally principle prefent in the furnace, fo in the fame proportion will the vitrid cruit encircling the working bars exhibit the prefence of that principle in the furnace.

IV. Agenda, or a Collection of Obfervations and Refearches, the Refults of wbicb may ferve as the Foundation for a Theory of the Eartb. By M. DE SAussure.

[Continued from Page 29.]

CH A P. XXII.

Exrors to be avoided in Obfervations refpeciing Geology.

I. HERE are fome errors into which people may readily fall when they have not had long experience in any given kind of obfervation, and againft which it is of importance to put beginners at leait on their guard.

2. One may be readily deceived in regard to the relative diftances of remote objects. All the ftars and planets appear to be at an equal diftance from us. Diftant mountains all appear to be in the fame plain. Thus thofe which are fituated very far behind the reft, feem to form one body with them ; fo that people believe they fee continued and uninterrupted chains when thcre are really none, and where the mountains, on the contrary, are infulated.

The abfolute diftance of objects, even when not very remote, is equally difficult to be afcertained on high mountains, 
tains, where the tranfparency of the air, and the abfence of vapours, deftroy the aërial perfpective. I have often imagined that I had only two or three hundred fteps to make in order to reach a fummit, the diftance of which from me was more than a league in a ftraight line.

3. There are a great many errors in regard to ftrata. Their great thicknefs may make one believe that there are none where they really exift. In the like manner, if the vertical ftrata, or thofe only very much inclined, prefent their plane to the eye of the obferver, he will think he fees fhapelefs and indivifible maftes; while, if their fections were feen, their divifions would readily be diftinguifhed. A mountain then muft be feen under afpects that interfect each other at right angles before we can pronounce that it is not divided by frata.

4. At other times accidental fiffures, but produced however by a caufe which is common to them, exhibit the appearance of ftrata when there are none; or when, if there are, their fituation is very different from that of thofe ftrata. It is the internal tiffue of the ftone only which in many cafes can determine whether the divifions obferved are the interftices between ftrata or mere fiffures; becaufe the itrata are conftantly parallel to the internal laminx, or fchiftous texture of the ftone. Cryftals, the lamellated texture of which may fometimes be confounded with a fchiftous texture, may afford an exception to this rule, by prefenting lamina perpendicular to the planes of the ftrata; but it is not difficult to diftinguifh them.

5. One may alfo form an erroneous opinion refpecting the direction of a mountain, or of its ftrata, when the eye is not fituated in their prolongation, or at leaft near it.

6. The apparent fituation of the ftrata may alfo lead into an error. They appear horizontal even when they are very much inclined, and when they are not feen but in a fection formed by a plane parallel to the common fection of their planes with the horizon. It is impoffible to judge of their inclination, and to meafure it with certainty, but on a fection perpendicular to the common fection, which I have juft mentioned. 
6. A. The greateft error, however, is that which may be committed in regard to the fuper-pofition of ftrata. I have often feen novices in the ftudy of mountains believe that one ftratum repofed on another; one of granite, for example, on one of flate; becaufe they found flate at the bottom of the mountain, and granite at the top; while the flate was only laid againft the bafe of the mountain, and the granite, on the other hand, was funk in the earth far below the flate. We muft not then fay, that a fratum is fituated below another, but when we really fee it extending itfelf below it.

7. And even when we diftinctly fee a rock placed above another, we muft examine whether that which is uppermoft does not occupy that fituation accidentally; whether it has not lipped, or rolled down, from a more elevated mountain; and, in the laft place, though they may be clofely connected, one muft examine whether their prefent fituation is really the fame in which they were formed, and whether they have not been reverfed, and united accidentally in a fituation contrary to that of their original formation.

8. One is frequently deceived, alfo, in regard to the nature of ftones and of mountains. Though a well-accuftomed eye may often judge at fome, and even a confiderable diftance, of the kind of ftone of which a mountain is compofed, fuch judgment is however often erroneous : mountains of granite, or gneifs, tender and deftructible, often affume, at a diftance, the round form of fecondary mountains; fometimes, alfo, mountains of calcareous fone, hard of their kind, and in ftrata either vertical or very much inclined, prefent the bold forms, the peaks, and harp-angled indentations of the granite fummits.

9. People are often deceived even on a near view. A ftone may have a forcign covering of mica, for example, while the interior part is of a very different nature.

10. Effervefeence with the nitrous acid is commonly confidered as a certain character of calcareous ftone; but this charaeter may be deceptive, fince barytes and magnefia effervefce alfo*: and we muft not confider it enough to touch

* And, on the other hand, there are calcareous ftones which do not effervelce.

Vor. V. 
a ftone with the nitrous acid, or to let fall a drop of the acid on its furface, fince the abforbing earth, whatever it is, may be only diffeminated between argillaceous or filiceous particles. We muft therefore immerfe a fragment of the ftone in a quantity of the acid fufficient to diffolve it entirely, if it be wholly foluble, and obferve whether there remains any refiduum that withftands folution.

Ir. The action of the air and of meteors often gives foffits appearances abfolutely different from thofe which they had before they were fubjected to it. We muft not then be fatiffied with a fuperficial examination: we mult found the rocks to the quick where the action of meteoric agents has not penetrated.

I2. People are often deceived, alfo, in confidering compound ftones as fimple ftones, when the compofition of them does not manifelt itfelf on the firft view, either on account of the fmallnefs of their compofing parts, or becaufe fome of thefe parts are each inclofed feparately in a covering which conceals the interior of them: One may guard againft this error by obferving the foffil in the fun with ftrong magnifying glaffes, after having moiftened its furface with water or the nitrous acid, and ftill better by expofing it gradually to the flame of the blow-pipe.

13. People are often deceived in regard to cryftallifation, either in the true form of the cryftals, or, above all, in taking for real cryftals parafite cryftals, or fuch as have been formed in the moulds made by cryftals of another kind. Thus we fee cryftals of quartz, petro-filex, and jafper, formed in the moulds made by calcareous cryftals, and which have affumed the form of the latter.

14. In regard to errors occafroned by ignorance of the diftinetive characters of foffils, and of the names proper for them, the only means of avoiding fuch errors is to ftudy with eare good authors; and, above all, colleetions formed, or at leaft arranged and titled, by able mineralogifts.

15. But when the flighteft doubt is entertained in regard to the denomination which ought to be given to any foffil, an exact defcription mult be made either of its external characters or its moft ftriking phyfical properties, fuch as weight 
and folubility*. If this defeription is well drawn up, the error refpecting the name may be rectified, and the obfervation will not be loft, as it would be were there any reafon to fufpect the juftnefs of the denomination, and no means of correcting it by a defcription $\uparrow$.

I6. When the characters of a foffil give it fuch a likenefs to another that it is found near the limits which feparate the genera or fpecies of thefe two foffils, we mult follow the example of Werner and his difciples; by marking that this forfil is intermediary, or forms a tranfition from the one fpecies to the other. For if we fhould afcribe it exclufively to the genus $A$, without noting the characters which bring it near to the genus $B$, another obferver, on feeing the fame foffil, might refer it to the genus $B$; and no one could know which of them was deceived.

I7. People are often deceived alfo by mixing opinion with obfervation, and giving the former for the latter; as wher people affert, that they have feen veftiges of extinguinhed volcanoes, becaufe they have feen black or porous ftones, or ftones of a prifmatic form, without deigning to defcribe them with care, but by qualifying them merely as lava or bafaltes.

18. In the laft place, a very frequent fource of error is, toa great a confidence in the fidelity of one's memory, or in the juftnefs of one's firft obfervations. Thefe two kinds of confidence go often hand in hand; and people cannot guard againft the errors, which are the confequence of them, but by noting down, on the fpot, all obfervations to which any importance is attached, efpecially if they are a little complex, and carry away fpecimens, with their characters carefully marked upon them, of the objects that are the fubject of

Hardnefs, refrangibility, eleetricity, \&c. H.

+ A perfon now dead, who in his time was confidered as a mineralogift, wrote to me that he had found marine fhells in granite. I begged him to give me an exact defcription of the ftone which he called granite. He did fo; but I perceived that the ftone was a free-ftone or fand-ftone, and the fpecimens he afterwards fent me proved that I was not deceived. We may here rccolledt Recupero's pyrites of Atna. The errors of this kind, arifing from falfe denominations, are innumerable; for an exabt knowledge of mineral fubltances is more dificult to be obtained, and nore rare, than is generally imagined. - Note of the AU THOR. 
thefe obfervations; for it is not fpecimens of rare objects merely that fhould be collected. The end, indeed, of the geological obferver is, not to form a cabinet of curiofities, but he muft carry away fragments of things apparently the moft common, when an exact determination of their nature may be interefting to theory. People may thus employ, with advantage, the means of confirming or rectifying their firft obfervations, and of making profound refeatches and comparifons iinpoffible to be made on the fpot *.

[To be continued.]

\section{Obfervations on Animal Electricity, and particularly that called Spontaneous. By J.J, HEM m RR.}

[Concluded from Page 7.]

IN a

a letter, dated June 21, 1787, which I received from $M$. De Sauflure, he confeffes that he had not made any farther experiments on animal electricity; and that he did not know whether any had been made by others. As I was convinced, however, that a complete knowledge of that electricity which is produced in the human body by the friction of the clothes, as well as fpontaneoufly, might be of great

* We think it our duty to fubjoin here fome advice to travellers in regard to the queftions which they may ank in the different towns.

Whence do they procure the materials proper for building; fuch as lime, plafter, tiles, flate, ftones of different kinds, and fand ? Do they barn tuif or coal; and where are they found? Where do they procure their potter's clay, fuller's eartlt, the clay ufed for refining fugar, their whetfornes and millftones? To obferve with what the ftreets are paved; of what ftone the fteps of ftairs ale formed; marks for boundarjes, \&c.; and to learn from what place they are brought. To afcertain whether wells or the foundation of houfes are dug; and whether there are in the neighbourhood any ravines or precipices. Thefe queftions will fetve to facilitate the means of obferving the nature of the ground, by pointing out the natural or artificial excavations that may txift in the neighbourhood, or which ought to be vifited. For the fame reafon it is proper to exatnine the hores of rivers. It will be of ufe alfo to take a general view of the country from the tops of towers and of the higheft fteeples. It will be of fome importance alfo to enquire, in the country, whether the inhabitants make ufe of lime, màr, plafter, coal, earth, or turf-afhes, for ma nuring their land; and from what places thefe fubftances are procured. $C$. 